\title{
Individual Practice and Cultural Context in the Transformation of Batak Toba House
}

\author{
Himasari Hanan \\ School of Architecture, Planning and Policy Development, \\ Institute Technology Bandung, Indonesia \\ hanan@ar.itb.ac.id
}

\begin{abstract}
Batak Toba people today are facing the dilemma of maintaining their tradition and keeping up to the modern way of living. This has resulted in cultural transformation of traditional houses, where modern utensils and new spaces are added with no reference to the original one. The traditional settlement of Huta Siallagan in Samosir Island North Sumatra begin to aspire urban standards of living, and traditional building practices are dying out because domestic life systems are changing. Traditional houses are undergoing transformation as they are more and more influenced by the modernizing effect of capital economy.
\end{abstract}

Keywords: Batak Toba, traditional house, transformation, modernization

eISSN 2514-751X @ C 2018. The Authors. Published for AMER ABRA cE-Bs by e-International Publishing House, Ltd., UK. This is an open access article under the CC BY-NC-ND license (http://creativecommons.org/licenses/bync-nd/4.0/). Peer-review under responsibility of AMER (Association of Malaysian Environment-Behaviour Researchers), ABRA (Association of Behavioural Researchers on Asians) and cE-Bs (Centre for EnvironmentBehaviour Studies), Faculty of Architecture, Planning \& Surveying, Universiti Teknologi MARA, Malaysia.

DOI: https://doi.org/10.21834/aje-bs.v3i7.272 


\subsection{Introduction}

The island of Samosir is in the middle of Lake Toba in North Sumatra, and Huta Siallagan is located circa 500 meter away from the lake Toba. The traditional settlement of Huta Sialagan is established by the clan Siallagan amidst of agricultural land, and at present preserved as an exclusively enclosed settlement for the descendants of the clan Siallagan.

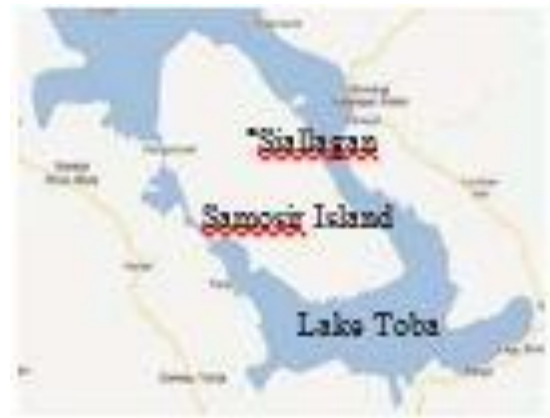

Figure 1: Map of Samosir

Source: (www.maps.google.com)

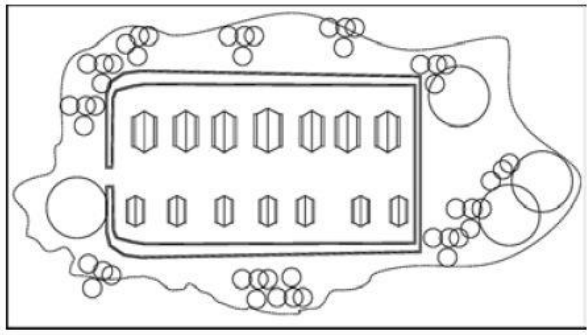

(a)

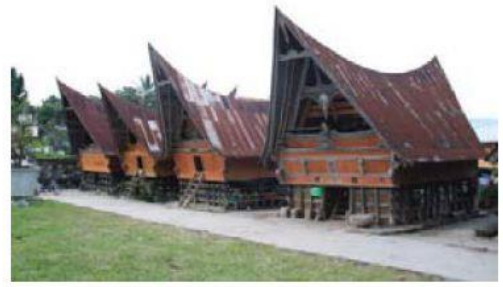

(b)

Figure 2: Typical Settlement of Batak Toba (a) Layout, (b) Perspective View of Houses Source: (Bukit, 2012)

A Batak Toba traditional settlement is rectangular in form and consists of two rows of buildings (houses and granaries) with in between a multifunction open space (alaman). The house is built on stilts with a steeply rising roof symbolizing three different world in Batak cosmology. The lower part of the house symbolizes the nether world (banua toru) in which devils live. The middle part represents the middle world (banua tonga) where people dwell and undergo their domestic life. The upper part symbolizes the upper world (banua ginjang), as the place for ancestors who protect people's life.

The traditional house has an open layout, and light enters the house through small windows, which makes the interior dark throughout the day. There is no furniture inside the house, and common space is being used by all inhabitants for all purposes. People put a stone hearth in the corner of space for cooking. The substructure consists of 1.5 meter high 
wooden structure that rests on flat stones, and it is used as stall and storage. All traditional houses nowadays have been expanded with new wooden or masonry buildings in response to the increasing demand of space for inhabitants. Most of the inhabitants, at present, make a living from tourism as tourist guides, in producing craft and souvenir, and performing art and music.

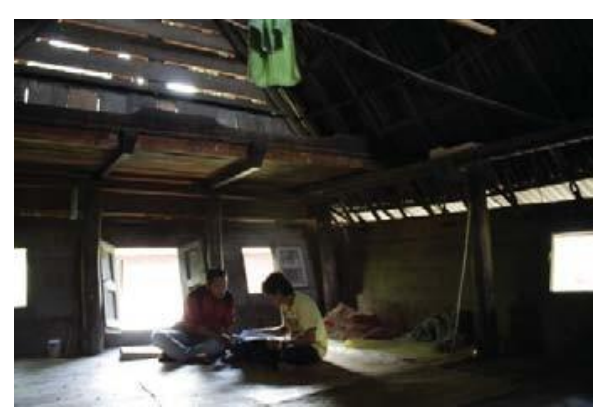

(a)

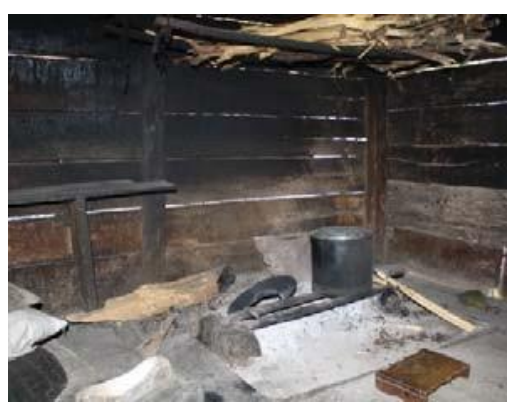

(b)

Figure 3: (a) Interior of a Traditional House, (b) Stone Hearth for Cooking Source: (Bukit, 2012)

\subsection{Literature Review}

John Storey (1996) discusses the phenomenon of people seeking identity in consumption, and the meaning of lives in what being consumed rather than in what being produced. People recognize themselves in commodities and find their soul in housing furniture, kitchen-set equipment, etc. The social control is anchored in the needs of new commodities, and advertisement has generated false needs to be "an extravagant person" and to use "trendy items".

Pierre Bourdieu proposed that culture is an arbitrarily constructed notion, and a social group constructs its own particular temporarily contingent notions of culture (Webster, 2011). His studies demonstrated that symbolic practices, as well as, economic practices are strategies in the competition for prestige or standing in the social hierarchy. All actions of people aim at the maximization of material or symbolic gain. Bourdieu indicates that lower class of society attempt to imitate the taste of upper class through the purchase of reproduction furniture.

Habraken meant that living environment is shaped by acts of transformation, and individual responsibility for one's own environment is essential for its sustainability (Teicher, 1998). Renewal and expansion of physical forms (buildings, streets and infrastructure) is people's acts to sustain the environment. Builder is the actor, who transforms the place to make sure the built environment endures. The interaction between people and their place is fundamental to the understanding of the transformation process. 


\subsection{Methodology}

The expansion of traditional houses and inhabitant's activities inside the house is observed and documented through field survey and interviewing the inhabitants. The method for analysis is adopted from N.J. Habraken, which classifies transformation of built environment in three orders: physical, territorial and cultural. The physical order relates to transformation that caused by different uses of household utensils and furniture, and partitioning of a room. The process is classified in three levels as follows:-

\begin{tabular}{|l|l|l|l|}
\hline Physical Objects & First level & Secondary level & Third level \\
\hline Household utensils & Oil-burning Stove & Magic jar, Dispenser, Blender & $\begin{array}{l}\text { Refrigerator, Washing } \\
\text { machine, Kitchen sink }\end{array}$ \\
\hline Furniture & Dining set & $\begin{array}{l}\text { Closet, Couch, } \\
\text { Cabinet, Bed }\end{array}$ & TV, Sofa, special furniture \\
\hline Partitioning & Bathroom & $\begin{array}{l}\text { Kitchen room, semi- } \\
\text { enclosed sleeping room }\end{array}$ & Private sleeping room \\
\hline $\begin{array}{l}\text { Building } \\
\text { component }\end{array}$ & $\begin{array}{l}\text { Wooden wall - floor } \\
\text {-frames, thatched } \\
\text { roof }\end{array}$ & $\begin{array}{l}\text { Manufactured wooden wall, } \\
\text { cement floor, one- direction } \\
\text { zinc roof }\end{array}$ & $\begin{array}{l}\text { Masonry wall, ceramic floor, } \\
\text { multiplex ceiling, two-direction } \\
\text { zinc roof }\end{array}$ \\
\hline
\end{tabular}

The second order relates to territoriality. The study will scrutinize how new spatial configuration in traditional houses is organized by territorial rules, and the relationship between physical form and territorial control. Changes in spatial configuration are classified as follows:-

\begin{tabular}{|l|l|l|l|}
\hline Spatial Configuration & First level & Secondary level & Third level \\
\hline Common room & Eating room & Living room & Formal sitting room \\
\hline Additional room & Bathroom, Kitchen & $\begin{array}{l}\text { Eating - Sleeping - Living } \\
\text { room }\end{array}$ & $\begin{array}{l}\text { Multi sleeping room/ bathroom/ } \\
\text { living room, a formal sitting room }\end{array}$ \\
\hline Expansion building & Subordinate to original & $\begin{array}{l}\text { Coherent to original, one- } \\
\text { story }\end{array}$ & Incoherent to original, two- story \\
\hline Building access & Additional side entrance & One new entrance & Two new entrance \\
\hline
\end{tabular}

The cultural order concerns about preferences of individuals in their acts, which make building forms and spatial configurations differs from socially determined tradition. The combination of formal order, territoriality and individual preferences represents cultural order by which each traditional house develops its sustainability. Key indicators for the analysis 
are as follows:-

\begin{tabular}{|l|l|l|l|}
\hline Spatial Meaning & First level & Secondary level & Third level \\
\hline Enclosure system & One entrance & Two entrances & More than two entrances \\
\hline Spatial form & Rectangular & Modified geometry & Organic \\
\hline Built area & Traditional size & 1.5 Xtraditional size & $>2$ X traditional size \\
\hline
\end{tabular}

Out of the 8 (eight) existing traditional houses, 2 (two) houses are excluded because they are not used as residential any more. Physical conditions of exterior and interior of the houses are photographed whereas spatial configurations are depicted in floor plan drawing. The cultural orders are analyzed through physical and territoriality changes taking place in the settlement and its correlation to inhabitant's profile and social life of the village.

\subsection{Results and Discussions}

\section{Pattern of Expansion}

The houses are expanded in several ways, in which some are stretched out along the original axis, and some are enlarged unevenly at the back. Some expansions are in the same level as the original one or at the ground level and some are made higher as two-story building. In average, new buildings are two times bigger than the original one, and most of them utilize different materials, such as masonry for wall and corrugated iron for roof. The house is usually inhabited by one single family with 2-3 children, and two houses in the village are inhabited by an extended family with daughter in law and grandchildren. All houses have added new functional rooms such as living room, sleeping room, bathroom and kitchen.

Table 1: Expansion of Traditional Houses

$\begin{array}{llllllll}\text { The house } & \begin{array}{l}\text { Nr. of } \\ \text { floor }\end{array} & \text { Area (sqm) } & \text { Nr. of inhabitants } & \begin{array}{l}\text { Sleeping } \\ \text { room }\end{array} & \begin{array}{l}\text { Living } \\ \text { room }\end{array} & \text { Bathroom } & \text { Kitchen } \\ \text { HS-R01 } & 1 & 34,3 & 3 & 1 & 1 & 1 & 1 \\ \text { HS - R02 } & 2 & 87,12 & 7 & 2 & 2 & 1 & 1 \\ \text { HS - R03 } & 1 & 48,8 & 7 & 1 & 1 & 1 & 1 \\ \text { HS - R06 } & 1 & 52,8 & 0 & 1 & 1 & 1 & 1 \\ \text { HS - R07 } & 2 & 104,3 & 5 & 3 & 2 & 2 & 1 \\ \text { HS - R08 } & 1 & 54,52 & 4 & 1 & 1 & 1 & 1\end{array}$

Source: (Bukit, 2012)

To the house (R01), modern, functional rooms are being added, such as private sleeping room, bathroom, kitchen and living room. The house (R02) is expanded with two-story building of masonry and wooden construction. The first floor is used for the kitchen, living room, and 
bathroom, and the second floor is for private activities such as sleeping. The house (R03) is expanded with a sleeping room, a kitchen, a bathroom and a dining room. The original house is kept as a common and sleeping room for the children. The house (R06) is expanded by adding a bathroom, a kitchen, a sleeping room and a living room. The acting chief of the settlement lives in house (R07). The original house is lavishly expanded in two-story building with 2 bathrooms, 3 sleeping rooms, 2 living rooms and 1 kitchen. The expansion of house (R06) and (R07) is interconnected. The house (R08) is expanded by a kitchen and an eating room, which is subsequently transformed to a workshop for producing handicraft and souvenir merchandise. The private sleeping room is arranged by partitioning the traditional house, and the bathroom is situated in a separate building at the backyard.

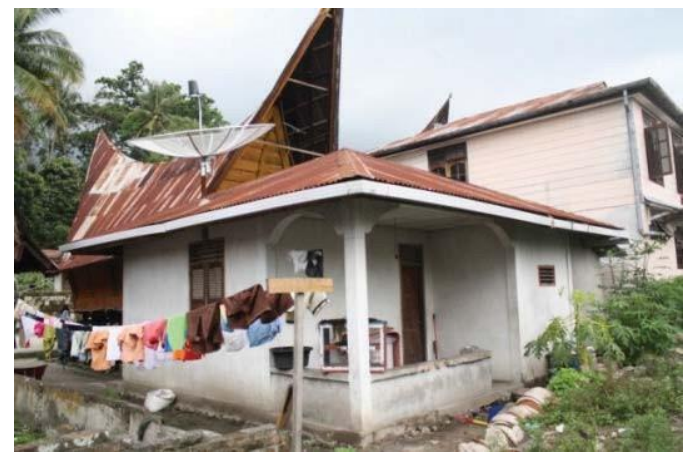

(a)

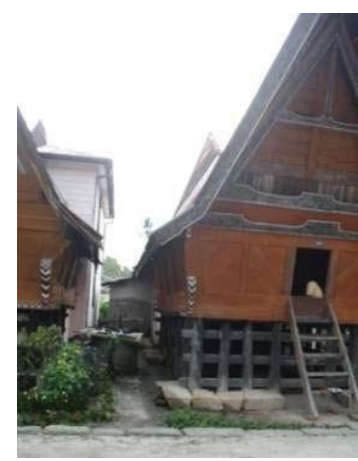

(b)

Figure 4: Traditional House (R02 \& R03) and its expansion

(a) Side Elevation (b) Front Elevation

Source: (Bukit, 2012)

\section{Modern Way of Living}

The most fundamental changes in domestic living are the way inhabitants practice their everyday life. First of all in the way people do the cooking; traditional stone stove is disposed and replaced with modern oil or gas-burning stove. Changes in cooking utensil have influenced spatial uses and stimulated new needs of equipments for cooking and preparing meals. Rice cooker, drinking water dispenser and food mixer/ blender are new objects that are immediately taken on board in everyday life, in some houses urban utensils such as washing machine and refrigerator are utilized as everyday equipments. New furniture such as closet, cabinet, couch, dining set, the bed, and TV set, is applied to imitate modern way of living. Spatial dimension and arrangements in traditional houses have ultimately been adjusted.

As modern way of living underlines privacy, the new building has adopted private rooms for functional uses and visual security. For daily activities, entry to the house is in the new building, whereas formal guests are welcomed through the entry point in the traditional house. Old and new building are interpreted as formal and informal place, as traditional and 
modern way of life, as symbolical and functional activities, and as public and private area. People comprehend tradition and everyday life as a consecutive life, yet separated. Hence, it is sensible to build an entirely different building typology next to the traditional one.

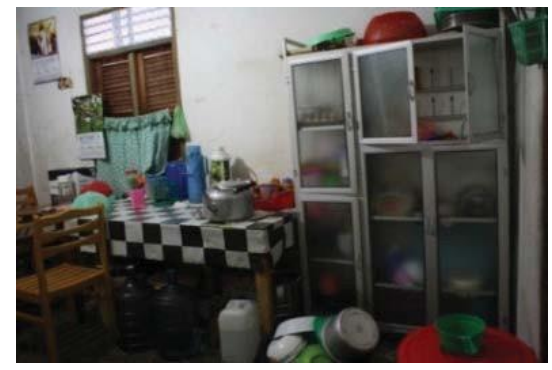

(a)

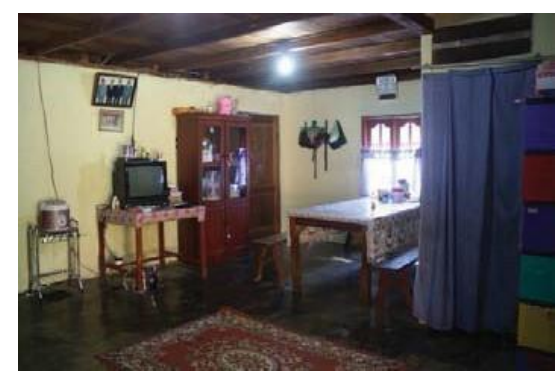

(b)

Figure 5: Modern WayofLiving (a)Dining Table Set (b)Electronic Utensil and Display Cabinet Source: (Bukit, 2012)

From the physical point of view, modernization is illustrated through selection of materials being used in new buildings. Manufactured materials such as ceramic tile and masonry have replaced bamboo and wooden structure. House on stilts is impractical and inefficient for modern living because people do not keep livestock in the house anymore. The new building is built up on ground level in a typical modern urban house with zinc roof and plastered masonry. When the expansion is two-story high, the lower part is imitating modern masonry construction, yet the upper part is made of wooden structure because of inadequate skill in structural framing. Inside the house, wooden panel is commonly applied for partitioning the space and staircase connecting old house to new building. The roof, in terms of its material, inclination, size and meaning, is the most distinct element that differentiates the appearance of old and new, of original and expansion.

\section{Cultural Transformation}

Traditional houses have comprehensible orientation to the mountain and the lake, and its geometry is arranged strictly to that symbolical direction. Houses create territoriality by standing side by side at a distance consistently toward an invariable direction. The expansion building, on the other hand, is situated variably, covering any available space to the right/ left or backward. As a consequence of irregular forms, the entrance to the building is also varied, some houses have access directly oriented toward the open space and others have entrances out of sight from the open space. Hereafter, the layout of houses is thoroughly changed, from a truly ordered and organized built environment into an organic settlement without regularity. Symbolical meaning of spatial configuration has transformed into a pragmatic organization exclusively controlled by individuals. On one hand, the collective territorial of the house is no longer retained, on the other hand, people indulgently tolerate interference from neighbors into one's territorial, by which it expresses continuity of communal spirit in dwelling environment. 

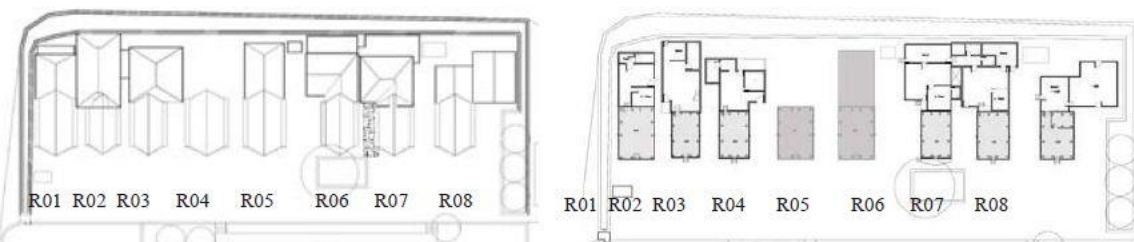

Figure 6: Pattern of Expansion in Huta Siallagan (a) Floor Plan, (b) Site Plan

Source: (Bukit, 2012)

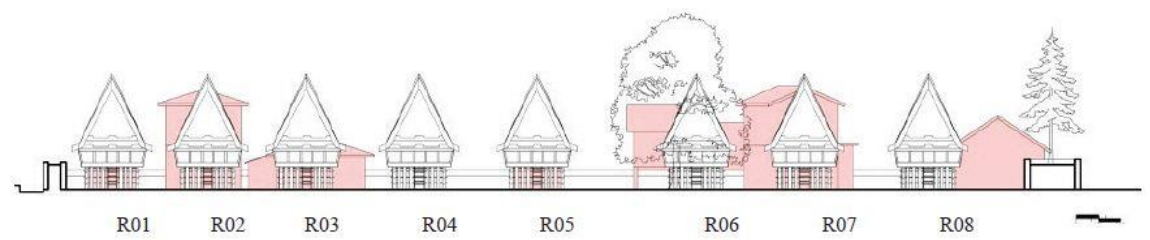

Figure 7: Structural Configuration of Traditional and Modern Building in Huta Siallagan Source: (Bukit, 2012)

A house as a collective place is transformed into functional spaces designated to a family where each function is made distinct through spatial configuration. Modern household utensils and furniture have underlined new meaning of spatial organization, as well. A dining table set situated in a space denotes a place for dining, and not for other activities. Activities such as cooking, body washing, sleeping, dining, are conducted separately from common activities: watching TV and entertaining guest. The place for entertaining guest is utilized as a pastiche of modern urban living by installing pictures of the family on wall, putting a sofa and a display cabinet filled with tea-set, decorative plate and carpeted floor. The inhabitants feel fashionable and well-off by having a room for entertaining guest, which is, in fact, in contrary to the traditional open space as a place forentertaining guest.

Inhabitants of Huta Siallagan, at present, have been involved with tourism activities, which are undertaken either collectively during ritual performances or individually in each house for handicrafts and souvenir production. The change from crop production into tourism generated employment has eventually transformed the spatial meaning and hierarchy within the settlement and the house. The defensible open space, which was a representative place for ritual purposes, is transformed to an accessible public place. The strictly secluded space in a traditional house has been redefined as a semi-private place utilized for entertaining guest, touristic attraction, and collective working area. The open space at the back of the house is now built up for functional rooms that become the truly private domains of the inhabitants.

\subsection{Conclusion}

The socially determined framework in utilizing space of a traditional house has been changed 106 
into individually preferences in managing activities and functional needs of inhabitants. Each family now has its own way of respecting the original house and developing its structure. What was customary and common understanding about dwelling is no longer taken for granted. Everyone is searching for his/ her own motives and opportunities in building and furnishing the house. Tourism has transformed the way of living, in which cash oriented value system has displaced traditional pattern of personal favors and privileges between landowners and laborers, and of kinship and ritual duties. The independent earning of each member provides the opportunity to purchase modern goods that will carry prestige to the family.

The expansion of traditional houses in Batak Toba is linked to a complex range of goals: wealth, status, comfort, autonomy, and stimulation. It is difficult to differentiate basic needs of inhabitants with desire of consumption in a changing world since basic needs may varies over time and space, and it is influenced by societal norms. According to Maslow's theory, a human being has a hierarchy in needs, in which lower order of physiological needs and safety will extend to higher order of belonging, esteem and self-actualization. It needs to be studied further whether there is a shift in needs among Batak Toba people. The understanding of individual needs may lead to a new model of preserving traditional houses that is outward-looking and accommodating inhabitant's contemporary needs. The future research on traditional houses should explore the way individual houses being developed within the specific historical and cultural context, and the needs of people with complex life histories.

\section{Acknowledgment}

My gratitude to Institute for Research and Community Services of Institut Teknologi Bandung for the full support in making this study possible.

\section{References}

Bonatz, D., Miksic, J., Neidel, J. D., \& Tjoa-Bonatz, M. L. (2009). From Distant Tales Archeology and Ethnohistory in theHighlandofSumatra. Cambridge: Scholars Publishing.

Building Research Institute (1973). Tradisional Buildings of Indonesia Vol. I Batak Toba. Jakarta: Ministry of Public Work and Electrical Power

Bukit, Elya Santa. (2012). Perluasan Bangunan Sebagai Proses Transformasi Rumah Tradisional. Studi Kasus Tiga PerkampunganTradisionalBatak TobadiPulau Samosir. ThesisofMagisterArsitekturITB, unpublished.

Dawson,Barry.(1994). The TraditionalArchitectureofIndonesia.London: Thames and Hudson Ltd

Pusat Penelitian dan Pengembangan Permukiman. (2010). Laporan Kegiatan Pengkajian Rumah Tradisional Etnis Batak di Propinsi Sumatera Utara. Binjai: Loka Teknologi Permukiman Medan

Schefold, Reimar, Nas, Peter JM, Domenig, Gaudenz, Wessing, Robert (eds). (2008). Indonesian Houses. Leiden: KITLV Press 
Hanan, H. / Asian Journal of Environment-Behaviour Studies (ajE-Bs), 3(7) Mar / Apr 2018 (p.99-108)

Sibeth,Achim.(1991). TheBatak, Peopleofthelsland ofSumatra.London: Thames and Hudson Ltd.

Storey, John. (1996). Cultural Studies and The Study of Popular Culture: Theories and Methods. Edinburgh: Edinburgh University Press Ltd.

Teicher, Jonathan (ed) (1998) NJ Habaraken. The structure of the ordinary: form and control in the built environment. Ambridge: The MITPress

Webster, Helena. (2011). Bourdieu for Architects. New York: Routledge 